\title{
MARK Wrathall: A PHILOSOPHICAL PLURALIST
}

\author{
MARK WRATHALL: UN FILÓSOFO PLURALISTA
}

\author{
MARK WRATHALL \\ University of California \\ MARTA FIGUERAS \\ marta.figueras@uab.cat \\ Universidad Autónoma de Barcelona \\ JOAN MÉNDEZ \\ jmendez@afpc.es \\ Presidente de la Asociación de Filosofía Práctica de Cataluña
}

RECIBIDO: $14 / 06 / 2012$

ACEPTADO: $31 / 07 / 2012$

\section{Marta Figueras - Joan Méndez}

Mark Wrathall is professor of Philosophy at the University of California, Riverside. His work focuses on phenomenology, existentialism, the philosophy of popular culture, and the philosophy of art. He is considered a leading interpreter of the philosophy of Martin Heidegger. And he is author of books like How to Read Heidegger (2005) and Heidegger and Unconcealment: Truth, Language, History (2010). Professor Wrathall is currently editing The Cambridge Companion to Heidegger's Being and Time (forthcoming 2012), and finishing up a book manuscript on Heidegger's later work.

Philosophy is often criticized, at least in Europe, for being too theoretical. And over the last century, it seems to have been confined to university classrooms. Now, at a time when the fragmentation of society and its values lead back to a reflection on the meaning of existence, the practical aspect of philosophy recovers the importance it had at its origins. In this context, what use is philosophy? 


\section{Mark Wrathall}

Part of the problem with our world is that we are so instrumentally minded. We value things to the extent that we can put them to use, exploit them, commodify them, and make them readily available for use and consumption. In that context, I think part of the use of philosophy is that it is useless. It's not a science, and it won't help us understand how to predict and explain the causal interactions of any domain of objects. It's not a technology, and it won't help us to control and dominate objects. Some would make philosophy into the "handmaid of the sciences," and take as its task the teaching of critical reasoning skills, the clarification of concepts, the development of rules of reasoning. But the justification for this rests ultimately on vestiges of the analytic/synthetic distinction, and the idea that there is a kind of conceptual analysis and reasoning process that is pure of any empirical content. There's no reason why scientists can't teach the kind of thinking that's needed in the empirical sciences, and do it in a way that's receptive to and tailored to the demands of empirical research within their specific domain. So even this claim for a special usefulness for philosophy is suspect.

What philosophy is very good at, by contrast, is questioning our assumptions about such things as use and usefulness, about our drive to instrumentalize the world. This is just an example, but where the sciences seek to explain an object, break it down, reconfigure it, render it flexible and available for ready use, philosophy asks why we feel an urge to understand, explain, control, and reconfigure the world. If usefulness is measured by the extent to which one advances such interest, philosophy is often the most useless of disciplines. And, in fact, this oldest of reproaches against philosophy - that it "corrupts the youth" - is a recognition of this fact.

And despite all this, people come to philosophy to explore their sense (usually a vague, inarticulate and inchoate sense) that something's not right with the prevailing ways we make sense of the world. If it's living up to its promise, philosophy will help them make sense of this concern.

\section{Marta Figueras - Joan Méndez}

What would you say that philosophy has brought in your own life, beyond becoming an academic occupation or profession? 


\section{Mark Wrathall}

Through practice in any discipline, the world teaches us how to see things in a new way. Painters experience color and form and composition in the world around them differently, as a result of practice in putting the visual world on canvas. Carpenters see grains and colors and textures differently as a result of bringing form to wood. I suppose that philosophers see meanings and ideas and justificatory or inferential relationships in a way that others do not. I live in constant wonder at the background of meaning, the "logic" of existence that shapes the things and events I encounter. I'd say that being a philosopher enriches my experience of art, of human events, of movies, of music, of love and friendship. Beyond that, philosophy has given me the perfect excuse to spend my time in conversation with interesting people in interesting places around the world.

\section{Marta Figueras - Joan Méndez}

What kind of philosophy is practiced in the U.S.? Is the practical aspect of this discipline being emphasized?

\section{Mark Wrathall}

I'm afraid that, for most of the past century, philosophy in the U.S. has been very much removed from the actual lifes of people. Analytic philosophy, which is the prevailing mode of philosophy in America, prides itself on its clear and rigorous style. And the level of technical proficiency in much of analytic philosophy is indeed very impressive. But the reality is that, without extensive training in philosophy, it's very difficult for most people to understand what's at stake in the analytic conversation.

Now I'm a philosophical pluralist. I think it would be a mistake for anyone to try to dictate that philosophy should be done in this way or that; that it must deal with these issues or those; that it must employ this method or that; that it must adopt a particular style. It would be a profoundly unphilosophical attitude to try to dictate such things. And still, I worry that philosophy is not doing enough to draw the broader community into the conversation. Philosophy has a unique contribution to 
make as we grapple with the important issues of our generation, and it would be a great shame if philosophers were to withdraw from the fray, or to speak only to each other.

\section{Marta Figueras - Joan Méndez}

So, If I understand correctly your words, you're defending, in fact, the practical aspect of philosophy, as the unique use that philosophy could have is, maybe, thinking about "the important issues of our generation". Is that right?

\section{Mark Wrathall}

Some of them, yes. I think the most important issues for each generation are the ones that challenge inherited practices and assumptions and ways of thinking. You might call these "thought provoking" challenges, because they disrupt our usual ways of dealing with the world and force us to think. I suspect that the unique contribution of philosophy is in training us to endure in thoughtfulness - to linger in these moments of breakdown, rather than trying to return as quickly as possible to a mindless way of managing the situation. From the perspective of calculative rationality, which wants to figure out how to control any situation as efficiently as possible, it is precisely that tendency to endure in thoughtfulness that makes philosophy appear so useless. And so philosophy (along with the other humanities), is increasingly called upon to prove that it can make a contribution to the larger global-technologicaleconomic order. I can't help but see this demand as an updated version of the oldest and longest standing accusation level led against philosophers. This accusation is that philosophers, far from better equipping their students to function in society, "corrupt the youth"

This is a serious accusation, for not just any possible way of forming a person's dispositions, discriminatory capacities and tastes amounts to an education - it is of course possible to form a person in such a way that he or she is less, not more, able to act in accordance with what the situation calls for. The opposite of an education is a corruption, where corruption is a way of forming an individual so as to under mine or destroy his or her skills, discriminatory capacities, and tastes. And I've essentially acknowledged in what I've said to this point that an education in thinking 
is almost by definition corrupting. Heidegger, too, has acknowledged as much: "we of today especially can only learn if weal ways at the same time unlearn. . . . We can only learn to think if we unlearn from the ground up what thinking's essence has been up until now."

But one should also distinguish two types of corruption - one type of corruption replaces understanding with a lack of understanding; another type of corruption replaces one kind of understanding with another kind of understanding. Or to put it more precisely, a philosophical corruption replaces a sense for what's important in the world, with a sensibility for the contingency of the world. By the standards of calculative thinking, such a Philosophical corruption may well produce a disutility. It will almost certain make us less efficient, and thus reduce the value of our students to the global-technological economy. What an education in thinking does offer is a higher estimation of the dignity of human beings. We are the beings who can take responsibility for our way of being in the world, rather than being driven by exigencies of efficiency, flexibility, and optionalization.

\section{Marta Figueras - Joan Méndez}

Do you think it is good to try to popularize philosophy? What risks do you see in the fact of trying to bring philosophy to the public? Is that appropriate? Necessary?

\section{Mark Wrathall}

I draw a distinction between the institution of philosophy and the practice of philosophy. For the institution of philosophy - the departments, research centers, societies, conferences, the journals and publishing arms of university presses - I think there's a risk today if we don't popularize philosophy. Universities and granting agencies are more and more focused on quantitative, demonstrable economic returns on their investments. I'm not sure this is a game that the institution of philosophy can win. If the institution is to survive, it needs to shine - it needs to attract and draw people to it, and show that it matters in a way that isn't easy to acknowledge within a straightforward cost-benefit analysis.

For the practice of philosophy, on the other hand, I do think that there is a risk in trying to popularize philosophy. Some philosophers worry about 
"watering down" philosophy, about making it dumb enough for public consumption. But that is not for me the concern. For me, the worry is instead the temptation to reduce philosophy to a menu of "positions" or viewpoints that can be taken up with respect to any particular problem. The practice of philosophy lives in a landscape that is unfamiliar to everyday, public forms of life. Or, to be more precise, philosophy thrives in experiencing the familiar and well-trod paths of everyday life as unfamiliar, as inviting new responses, as opening up on to previously unseen vistas. The practice of philosophy involves a tentative, halting questioning that resists the temptation to fall back on familiar concepts and categories. In my experience, it works best amongst a small group of interlocutors, who trust each other and are not afraid to make mistakes, to be corrected, to wander into a dead end and painstakingly retrace their steps, etc. This practice is very difficult to maintain in a public setting.

\section{Marta Figueras - Joan Méndez}

This reminds me of the Kantian assertion: "You cannot learn philosophy, can only learn to philosophize."

\section{Mark Wrathall}

That's very well put. Philosophy is a practice. It's an attitude. It's a way of exploring and disclosing the world. The moment it becomes a set of propositions that one can learn, or a method that one can apply formulaically, it's no longer philosophy - it's dogma or science.

\section{Marta Figueras - Joan Méndez}

Metaphysics is perhaps one of the branches of Philosophy that could provide more light on the loss of the original meaning of existence, as latent (and so visible) today. From what perspective you are working so theoretical aspect but at the same time, so essential to our practical life?

\section{Mark Wrathall}

Yes, I agree. For those who are concerned about the emptiness and banality of contemporary life, I think a metaphysical inquiry into the structure of existence can be quite illuminating. My own thinking often turns around this very issue. I'm currently involved, for instance, in 
trying to get clear about different ways of experiencing temporality. The nature of temporality is a very traditional metaphysical issue, but philosophers tend to focus on the temporality of causal interactions. This misses completely the way that time structures the spaces and activities of everyday life. When we are with friends and loved ones, when we are working, when we are at a music concert, when we experience the sacred, when we are lost in thought or remembrance - each of these experiences involves a different way of relating our involvement in the moment with our recollections and anticipations. And they are incompatible with the increasingly pervasive temporality of contemporary life - the temporality of consumption, of experimenting with (but not committing to) options, of multi-tasking.

\section{Marta Figueras - Joan Méndez}

Do you think reading Martin Heidegger's works could help us to analyze the actual moment of our societies? In which sense?

\section{Mark Wrathall}

I return again and again to Heidegger's diagnosis of the pathologies of our technological age. I think Heidegger was way ahead of everybody in recognizing and seeing what's going on in our world. There is no question that modern technology has brought tremendous benefits to human beings. Technology has contributed to dramatic increases in health and wealth as it has improved the supply of the basic commodities of life - housing, food, clothing, as well as medicines, healthcare. In addition, developments in technologies of transportation and communication have enriched our lives by bringing variety and opening up endless options for entertainment.

Yet many people feel an ambivalence about technology, a certain malaise in the presence of the increasing technologization of every aspect of our lives. This ambivalence is captured nicely in a VCU Life Sciences Survey on public attitudes toward technology. In year after year of the survey, approximately $90 \%$ of Americans agree that "scientific research is essential for improving the quality of human lives," and about the same percentage hold that, "on the whole, developments in new technology helped make society better."And yet approximately 50\% of Americans 
surveyed consistently hold that "scientific research has created as many problems for society as it has solutions."

Moreover, the broad consensus view that science and technology improve life becomes much more divided when questions were asked about specific technologies like genetic therapy. Interestingly enough, the survey posed the question in terms of when "science goes too far." $94 \%$ thought it would be "going too far" to use biotechnology to change a baby's eye and hair color, for instance. And 54\% even believed it was "going too far" to use genetic therapy to reduce a baby's risk of serious disease. $61 \%$ said they would be unlikely to use genetic therapies to slow down the process of aging (even though 92\% said they believed that "new technology used in medicine allows people to live longer and better").

In a more personal, anecdotal level, many people I talk to express a feeling of oppression in the face of technology. They hate feeling driven to check email constantly, and yet they can't resist the urge. With considerable guilt, friends will report episodes of turning into internet surfing zombies - waking up from a cyber-coma to realize they've wasted a day or a night. We feel, in a myriad of small and subtle ways, that technology has invaded domains in which it doesn't really belong, and from which it detracts.

This ambivalence toward technology - this feeling of malaise even in the face of the undeniable benefits that technologization has brought - points to something important about our technological age.

On Heidegger's account of technology, the malaise is rooted in ontology - in a sense that we are distorting ourselves and the entities we encounter in the world by imposing on them a mode of being that doesn't let them be in the way that is most the irown. The problem with technology is a problem of boundaries - of recognizing what entities are allowed to be the irown by technology, and what entities are not; and then having the restraint (Verhaltenheit) not to force non-technological entities into a technological frame. Heidegger calls the ability to respect such boundaries "having a free relationship to technology". It amounts to learning to resist the demands of technology - indeed, to being no longer even subject to these demands where they would be inappropriate. 


\section{Marta Figueras - Joan Méndez}

I agree. But... when you talk about Heidegger, I notice you talk about the latest of his works. What's about the ontology that Heidegger designs in Being and Time, for example. Is it also usefull in this context of practical philosophy?

\section{Mark Wrathall}

Yes, I think so. The way Heidegger analyzed the temporality of everyday existence in Being and Time lies at the root of a lot of the things I've been saying here. And it's also a topic of some of my current work. Just one example - I'm very interested in the idea that different ways of organizing time give rise to different experiences of space. I spoke last fall at a conference in Rome devoted to the problem of protecting sacred spaces. I found Heidegger's account of temporality to be very useful here. There is a particular temporal pattern that governs equipmental contexts - when I am using tools and raw materials to construct an object, for example, I am oriented toward the future by way of a definite expectation of what is going to result from my actions. But that kind of expectation is not compatible with an experience of the sacred in a holy place or cathedral or mosque or whatever. To be open to an experience of the sacred, one must be ready to be dis-oriented, to have one's expectations altered. That suggests that the protection of sacred spaces requires us to not introduce them into an economy of use, or think of them as somehow contributing to the quality of life. The sacred can't remain sacred if it is turned into an option, and commodity that offers a particular quality of aesthetic experience. 



\section{RESEÑAS BIBLIOGRÁFICAS}

REVIEWS 
